\title{
The Role of The School Committee: Multi-Site Study in MTS Darud Da'wah Wal-Irsyad Kersik Putih and MTS State 1 Tanah Bumbu
}

\author{
Muhammad Islam *, Ahmad Suriansyah, Metroyadi \\ Master Program of Education Management, Universitas Lambung Mangkurat, Banjarmasin 70123, \\ Indonesia
}

Article history:

Submission December 2019

Revised July 2020

Accepted July 2020

${ }^{*}$ Corresponding author:

E-mail:

muh.islam86alank@gmail.com

\begin{abstract}
Schools are institutions that provide formal and non-formal education services that should have the ability to improve their quality in improving human resources through community participation. Community participation is needed in the management of educational services following the needs of the school. To accommodate public participation, a forum called the school committee was formed. The objective of this study is to describe the extent role of school committees in improving student learning achievement as supporters, controllers, and mediators. This study uses a qualitative approach with a multi-site design. Data were collected using in-depth interviews, participatory observation, and documentary analysis. obtained from this study indicate that the school committee plays an active role in improving student learning outcomes. This research recommends that schools need to implement several performance indicators related to their role as considerers, supporters, controllers, and mediators in improving student learning achievement and education quality.
\end{abstract}

Keywords: School committee, learning achievement, school quality

\section{Introduction}

Education plays an essential role in improving the quality of human resources. The process is qualified when it can create an active, creative, innovative, and fun-filled atmosphere to achieve set educational goals properly. According to Metroyadi (2005), stated that is declared qualified when the academic and non-academic fields are high, with the ability to satisfy institutional needs and provide outstanding. The existence of synergy between the school committee and the community aids in developing education. Therefore, the community channels various ideas and participation in advancing education (Suriansyah \& Aslamiah, 2018).

By optimizing the empowerment of school committees, including overseeing financial use, the transparency of the use of education fund allocations becomes more accountable. This creates a more innovative education due to the birth of bright and creative ideas of all parties related (Suriansyah et al., 2014). There are many problems associated with improving the educational quality of schools, most of which overcome with outside help. Therefore, schools need the active participation and assistance of families and communities to successfully implement their educational programs (Aslamiah, 2015). The success associated with the implementation of education is not only the responsibility of the government, but the provincial, district, parents, and the community (Suhaimi \& Efendi, 2018).

However, the concept of community participation and starting to be implemented in Indonesia. The essence of applying the education unit and its stakeholders is to provide highquality services (Suriansyah \& Aslamiah, 
2018). Good collaboration is needed from the school community, family, and community or other elements systematically for proper management through its roles (Shodiqin, 2014).

According to Hasbullah the school committee carries out its function by partnering with the principal in providing educational resources for proper management and to facilitate teachers' and students' learning efficiency. The existence of synergy between the school committee and the community helps in developing quality education. This enables the community to channel various ideas and participation in advancing education in their area (Suhaimi \& Efendi, 2018). The community plays the role of participating in improving the quality of education, through donations, ideas, and innovations (Normianti et al., 2019).

There are numerous educational problems in schools that cannot be eliminated without the assistance of some external parties (Alamsyah et al., 2019). To implement programs, schools need the active participation of families and communities, in various educational programs (Suhaimi \& Khalik, 2018). The phenomenon found by researchers in MTs Darud Da'wah Wal-Irsyad (DDI) Kersik Putih and MTs Negeri 1 Tanah Bumbu in the role of school committees, was that there is an increase in the teaching and learning process. This study aims to describe and provide indepth roles, constraints, and alternative solutions in overcoming problems to the role of school committees.

\section{Material and Methods}

The qualitative approach was used due to its natural ability to unveil events as they occur with in-depth exploration. Data was obtained through observations and interviews from various sources and systematically processed. Suriansyah (2002) stated that qualitative methods are based on phenomenological philosophy that uses appreciation. While Suriansyah \& Aslamiah (2018) stated that descriptive research is used to obtain data from various sources, both verbally and in written form. The qualitative method seeks to understand and interpret the meaning of an event of human interaction in a particular situation (Suriansyah et al..,2014). This method was used to provide a detailed explanation of the role played by the school committee in improving student learning achievement (Metroyadi, 2015). The research subject is the source of the data requested for information following the problem. The intended source of data is the subject (Arikunto, 2002).

Furthermore, data were collected through documentation, observation, and interviews to absorb or determine continuous actions (Emzir, 2008). After collection, it is summarized and summarized for easy analysis.

\section{Results and Discussion \\ Obstacles or the role of school committeesin improving learning achievement}

The empowerment of the school committe

The MTs DDI Kersik Putih and MTs 1 district effort to empower the role of its committee was carried out by creating a forum to discuss its work program specifically. The empowerment has not shown the right direction as an organization that accommodates school residents.

\section{School decisions and policies}

The daily decisions relating to being a good school have become the autonomy of educators in determining students' grades. School committees are not involved in education service at MTs DDI Kersik Putih and MTs Negeri 1 Tanah Bumbu Regency because they play a more advisory or consultant role. They are invited to public and open school meetings, semester workshops, discussions, and annual work programs. The additional effort made in creating openness is to provide varieties of information relating to school activities through oral and forums.

\section{Funding Support}

School tries to obtain financial support, ideas and facilities from committees in MTs DDI Kersik Putih and MTs Negeri 1 Tanah Bumbu District were by inviting the public to its meetings, providing information on the academic and non-academic activities related to the use of funds in RAPBS and annual work program discussion meetings. Besides, the school is always active in providing various information through oral and written meetings. 
Committee involvement in implementing activities

The committees also participate in activities carried out during school programs and in decision making. They contribute to empowerment efforts, which are established and coordinated with meetings held once every month to create room for discussion. During this period, monitoring activities are carried out even though the school committee is still in a vacuum. The form of a school committee supported by the school program has been in the form of financial and material support for school progress. However, an atmosphere of openness existed between the committee in establishing cooperation, and it involved in various programs, from the planning, implementation, and decision making stages. The impact associated with their performance in improving educational quality is by contributing to improving school services, It plays a significant impact in increasing stakeholder participation, and support/manage ideas.

From the results of these studies, alternative strategies are produced, therefore, the role of the MTs DDI Kersik Putih and MTs 1 district school committee Tanah Tanah is maximized through the compilation of regulations in accordance to its committee with its rights and obligations to carry out its fungtion following the rules set. This is in addition to its ability to handle financial management and improve the educational quality in schools.

Solution to overcoming obstacles associated with the role of school committees in improving learning

Meeting and discussions

This is achieved in the form of routine, and incidental meetings held on joint initiatives between the school and its administrators. The discussion forum currently utilized is quite effective and productive in providing various inputs for the school to manage its programs. The established cooperation between the school and the committee cannot be separated from the creation of an open atmosphere for them to carry out their various activities.
School committees are invited in public and open meetings, workshops, discussions, and annual program discussions.

\section{The suitability of school decisions/policies}

The policies have more discussion based on its provisions. School committee empowerment is carried out using consultation between the school and committee in implementing programs, for example, in the KTSP preparation activities, organizing more effective RAPBS programs, etc. Everything is carried out by discussing all problems, complaints, and progress related to the implementation of school programs. Decisions/policies taken by schools are made based on consensus agreement with its committee. It is generally strategic and regulated by the committee, such as participating in SBC, determining the amount of contribution, and student tuition fees.

Efforts to Empower School Committees were carried out by creating a dialogue forum to discuss its work program specifically. This method is carried out in the form of routine, and incidental meetings held on joint initiatives. The forum has been running quite effective and productive.

The established cooperation between the school and committee cannot be separated from the creation of a conducive and open atmosphere for them to carry out their respective roles as members.

\section{Funding support from competent parties}

Empowering the education board and school committee might be an alternative way to exercise control. School committee involvement starts with the preparation of the Budget. However, the process of recruiting members of the education board and school committee needs to be transparent and democratic. Currently, school committee members are more determined by their proximity to the principal. A process like this certainly affects their existence, which is easily manipulated. It is important to construct a mechanism for recruiting members with a good track record, high morale, integrity, and credibility, with the ability to support the 
school's performance and control its education funds without corruption.

To optimize the recruitment process, it is necessary to refer to the base, which can guide schools during selections. The basic references consist of inter alia, the rules, teams, mechanisms, methods, measurement tools, and stages of recruitment. This is important to reduce subjectivity and the interests of the principal.

Four principles need to be fulfilled in the recruitment process of school committee members, namely transparency, accountability, fairness, and participation. Transparency is defined as the process of selecting and determining criteria that need to be publicly known. Accountability is the selection process that uses methods and selection techniques for accountability. Fairness refers to the fact that all participating candidates need to pass through the same selection process. While participatory is the selection process that needs to be open opportunities for the community to provide constructive input, criticism, and suggestions.

The empowerment of the school committee is expected to be able to encourage reforms in managing the education budget, which needs to be followed by the community and parents' contributions.

\section{School committees act as program planners}

Administrators are chosen due to their skills and the network of relationships they possess. Members are generally elected through deliberation and not through an election. Former members of BP3 were reappointed, and their work expanded. The proper management of the school committee is determined by a decree from the principal, through the semester, monthly or yearly meetings to deliberate on the planning, implementation, and funding of the school development plan as well as matters relating to the academic calendar.

The programs developed at these meetings show a tendency to focus on the physical improvement of schools. Generally, the activities to improve educational quality not to refer to important issues of teaching and learning. However, the positive impact of joint planning and program development is seen in many schools. The committee increases the learning, teacher welfare, provides better facilities, and improves the physical environment. However, in implementing its work program, some obstacles were experienced. The most prominent is its effort to fund the program independently, mainly because planning is first conducted. Committees and schools carry out entrepreneurship in this matter by using various means to raise funds.

Out of the four roles of school committees, the dominant role is often seen as a criterion for the effectiveness in terms of collecting funds. Activities that require the thought and energy of the committee are not considered an effective sign by the majority of respondents. Many consider that a good working environment and qualified members are very important to improve the quality of teaching and learning in schools. The policy of optimizing the roles and functions of the School Committee is a policy step that plays an important role and implications in meeting the need for the realization of educational programs in schools that are following the management of its concept.

Table 1: Cross case research findings

\begin{tabular}{|c|c|c|c|}
\hline \multirow{2}{*}{ No } & \multirow{2}{*}{ Focus } & \multicolumn{2}{|c|}{ Research Findings } \\
\hline & & at MTs DDI KersiPutih & at MTs Negeri 1 Tanah Bumbu \\
\hline 1. & $\begin{array}{l}\text { The Role of } \\
\text { School Com- } \\
\text { mittees }\end{array}$ & $\begin{array}{l}\text { An increase in the restriction of student's } \\
\text { learning in MTs DDI KersikPutih, through } \\
\text { the participation of the school committee } \\
\text { and principal in improving its facilities and } \\
\text { infrastructure, to provide a comfortable } \\
\text { learning environment for students. }\end{array}$ & $\begin{array}{l}\text { An increase in student's learning achieve- } \\
\text { ment in MTs Negeri } 1 \text { Tanah Bumbu with } \\
\text { the involvement of the school committee in } \\
\text { improving cooperative relations with the } \\
\text { community, and parents of students. }\end{array}$ \\
\hline
\end{tabular}


Tabel 2. Community participation and the role of school committees

\begin{tabular}{|c|c|c|c|}
\hline Considerations & Supporters & Controller & Mediator \\
\hline $\begin{array}{l}\text { Accommodate and ana- } \\
\text { lyze aspirations, ideas, } \\
\text { demands, and various } \\
\text { educational needs aimed } \\
\text { at schools. }\end{array}$ & $\begin{array}{c}\text { Raise funds for } \\
\text { school residents and } \\
\text { the community in } \\
\text { particular to improve } \\
\text { student's achieve- } \\
\text { ment. }\end{array}$ & $\begin{array}{l}\text { Provide input, consider- } \\
\text { ations, and recommen- } \\
\text { dations to schools re- } \\
\text { garding education poli- } \\
\text { cies and programs, edu- } \\
\text { cation budget plans and } \\
\text { expenditures, perfor- } \\
\text { mance criteria, educa- } \\
\text { tional facilities, and mat- } \\
\text { ters relating to educa- } \\
\text { tion. }\end{array}$ & $\begin{array}{l}\text { Collaborating with the } \\
\text { community and govern- } \\
\text { ment regarding funds to } \\
\text { improve its perfor- } \\
\text { mance. }\end{array}$ \\
\hline
\end{tabular}

\section{Conclusion and Recommendation}

From the research and discussion, it is concluded that the role of school committees with the understanding of its committee and principals in active participation in implementing work programs. Furthermore, decisions that are not in discussion with the school committee have not been carried out following the provisions, with poor funding. While the solution to overcome the obstacles of the role of the School Committee in improving achievement includes empowerment, suitability, funding, and planning. Such, schools need to be more active in disseminating information on the existence of committees and the functions/roles carried out by its committees, principal, and all parties involved to create a better understanding of the purpose to improve the quality of the school

\section{Acknowledgment}

The authors are grateful to the Master of Education Management Program, Lambung Mangkurat University, North Banjarmasin, 70124, South Kalimantan, for supporting this research.

\section{References}

Alamsyah, Aslamiah, \& Muhyadi, R. (2019). School based management implementation to improve school quality of multi sites study in SBN Alalak Selatan 2 and SDN Alalak Selatan 4 Banjarmasin City. International Journal of Scientific Development and Research (IJSDR), 4(1), 34-43.

Arikunto, S. (2006). Prosedur penelitian suatu pendekatan praktik. Jakarta: Rineka Cipta.

Aslamiah. (2015). Hubungan kepemimpinan transformasional kepala sekolah, kepuasan kerja, komitmen organisasi dan organizational citizenship behavior (OCB) dengan kinerja guru Sekolah Dasar Negeri di kota Banjarmasin. Disertasi. Retrieved from Program Studi Manajemen Pendidikan Pascasarjana Universitas Negeri Malang, Jawa Timur, Indonesia.

Emzir. (2008). Metodologi penelitian Pendidikan: Kualitatif \& kuantitatif: korelasional, eksperimen, ex post facto, etnografi, grounded theory, action research. Jakarta: Raja Grafindo Persada.

Metroyadi. (2015). Analisis implementasi peran komite sekolah pada SMP Negeri di kota Banjarmasin. (Unpublished master's thesis). Universitas Lambung Mangkurat, Banjarmasin, Indonesia.

Metroyadi. (2015). Perencenaan partisipastif dalam peningkatan profesionalisme guru pada sekolah berprestasi (studi multi kasus pada SMKN 5 Banjarmasin, MAN 2 Banjarmasin dan SMA 7 Banjarmasin). Disertasi. Universitas Negeri Malang, Jawa Timur, Indonesia.

Normianti, H., Aslamiah, \& Suhaimi. (2019). Relationship of transformational leaders of principal, teacher motivation, teacher organization commitments with performance of primary school teachers in Labuan Amas Selaran, Indonesia. European Journal of Education Studies, 5(11), 123-141. Shodiqin, A. (2014). Analisis peran komite sekolah dalam meningkatkan prestasi belajar di Sekolah Dasar Negeri 9 Kampung Baru Kecamatan Simpang Empat Kabupaten Tanah Bumbu. Unpublished master's thesis. Universitas Islam Kalimantan, Banjarmasin, Indonesia.

Suhaimi, \& Khalik, A. (2018). Kepemimpinan transformasional kepala sekolah pada SMP 4 Muhammadiyah. Jurnal Penelitian Tindakan dan Pendidikan, 4 (1), 37-46.

Suhaimi \& Efendi, N. (2018). Hubungan peran kepala sekolah dan sikap terhadap profesi guru dengan prestasi kerja guru SMA Negeri di Kabupaten Hulu Sungai Selatan. LETTERA: Jurnal Ilmiah Kependidikan, 13(1), 73-83. 
M Islam, A Suriansyah, Metroyadi, 2020 / The role of school committee: Multi-site study in MTS Darud Da'wah Wal-Irsyad Kersik Putih

Suriansyah, A. (2002). Manajemen hubungan sekolah dengan masyarakat dalam rangka pemberdayaan masyarakat. Jakarta: PT. Raja Grafindo Persada.

Suriansyah, Aa, \& Aslamiah. (2018). Strategi kepemimpinan kepala sekolah, guru, orang tua, dan masyarakat dalam membentuk karakter siswa, Banjarmasin, Indonesia. Cakrawala Pendidikan, 2, 243-247.

Suriansyah, A., Aslamiah \& Sulaiman. (2014). Strategi pembelajaran. Jakarta: Raja Grafindo Persada. 